\title{
ANOMALY OF THE NATURAL CONSTANT ELECTRIC FIELD OF LARGE MAGNITUDE IN TECHNOGENICALLY DISTURBED LAYERS OF ANTHRACITE
}

In the Eastern Donbass, a large positive anomaly of a constant natural electric field (NF) (with an intensity of up to $2500 \mathrm{mV}$ and a width of more than $1 \mathrm{~km}$ ) was obtained on the mining branch of a mine that was liquidated by wet conservation method, developing coal seams of A1-grade anthracite. Repeated (control) measurements made two months later confirmed the presence of this anomaly. The author's interpretation of the existing natural phenomenon is reduced to a multi-level, step-by-step analysis of the conditions for the formation of the field of natural potentials in the massifs of coal-bearing rocks technologically and tectonically disturbed by mining.

Purpose. To identify regularities of the formation of a positive anomaly of a constant natural electric field of a large magnitude on the mining branch of a liquidated mine.

Methodology. Field geophysical work using natural field methods and electropotential tomographic sounding. Multi-level, step-by-step analysis of the conditions for the formation of the field of natural potentials in the massifs of coal-bearing rocks technogenically and tectonically disturbed by mining.

Findings. A model of a hydroelectrokinetic section is developed in which the developed space is represented by a watered extended and power-varying flat layer of multi-block fractured rocks with the formation of a water-absorbing funnel at the site of tectonic disturbance, as a structure of high-speed absorption of mine water, resulting in the formation of a positive NF anomaly of more than 2, 3 Volt.

Originality. Detection and justification of the formation of a positive anomaly of the natural constant electric field, which is unique by its intensity and width, on the territory of the mining branch of the liquidated coal mine in the Eastern Donbass.

Practical value. The uniqueness of the identified positive NF anomaly initiates a discussion about the nature of its formation and proves the feasibility of using the natural field method in solving problems of hydroecological, gas, and other types of monitoring in coal regions.

Keyword: natural permanent electric field, Eastern Donbass, anthracite, technogenically disturbed layers, electrical exploration, mining branches of closed mines

Introduction. Information about the ability of anthracite layers for spontaneous polarization (PS) appeared in the early 30 s of the $20^{\text {th }}$ century simultaneously with the use of PS logging in the coal fields of the Eastern Donbass. Experimental electro-prospecting observations were also made to study the field of natural potentials (NP) in conditions of inclined occurrence of anthracite layers that come out on the day surface or under sediments. The conducted research served as the basis for creating hypotheses for the formation of the NP field in the coal bed with anthracite strata. The results were discussed in scientific publications and articles [1].

Anomalous NP values are indexed in current practice in ground electrical survey as Unp, and in Ups logging methods as Ups. It was found that anthracite layers appear in the form of negative Unp on the day surface, and in wells - in the form of positive Ups anomalies. The registered natural field potentials (taking into account the sign,+- ) in wells are more than an order of magnitude higher, since there is no damping effect of cover deposits. In the presence of tectonic discontinuities and mine workings in coal bearing deposits the sign of anomalies PS in most cases changes. Ups values can be abnormally low and less often abnormally high [1]. On the territories of closed and water-filled coal mines, the NP method has not been used before. Modern studies on the nature of the formation of NP and PS fields are performed mainly in ore deposits [2, 3-5]. Anthracite deposits are covered to a lesser extent. The NP method is also used for searching and mapping places of infiltration and discharge of underground water [6, 7].

There are some cases of registration of very significant NP anomalies in the amplitude as a result of redox processes in ore deposits and also as a result of possible electrokinetic or filtration processes observed in mountains with low mineralization of underground water $[2,8]$.

Conditions, methods and results of work. Geophysical studies on the NP together with the method of electropotential to-

(C) Fomenko N.E., 2020 mographic sounding (EPTS) were carried out along the stretch of the sloping coal seam $m_{8}^{1}$ on the territory of the mountain branches of the Krasnodonetskaya and Sinegorskaya coal mines in the Krasnodonets coal-bearing region of the Eastern Donbass. The geological structure of the district includes formations $C_{2}^{4} C_{2}^{7}$ of the middle division and $C_{3}^{1}$ of the upper division of the Carboniferous system, as well as rocks of Paleogene, Neogene and Quaternary ages. The main tectonic elements of the area are the Krasnodonets syncline and its accompanying multistage discharges of relatively large amplitude $(60-70 \mathrm{~m})$ with apophyses of smaller discontinuous disturbances. The stretch discharges agree. The North wing of the syncline is steep (angles of incidence $60-80^{\circ}$ ), and the South wing is flat $\left(10-20^{\circ}\right)$. The $m_{8}^{1}$ coal seam was developed within the southern wing from the late $19^{\text {th }}$ century to the end of the $20^{\text {th }}$ century. Above, there lie coal seams $m_{9}, m_{9}^{0}, m_{9}^{1}$ of lower capacity. The degree of coal metamorphism is A1. The $m_{8}^{1}$ formation is developed from the boundary of its contact with cover deposits to a depth of 500-600 m. The formation was not developed in difficult terrain areas of the day surface (beams, ravines) and in places of mine shafts, slopes, etc., that come out on the day surface. There were left the security pillars of coal provided by the project. In addition, with a low power of cover deposits in contact with an unstable roof, under this roof, it was envisaged to leave the calculated power of the coal layer. The process of closing the mines was carried out at the beginning of the $21^{s t}$ century. The "wet" method was used, i.e. by natural flooding of mine workings with underground water.

Fig. 1 shows a geological map showing the position of the geophysical profile, a lithological column of the ventilation shaft at Sinegorskaya mine, which shows the areas of outflow (discharge) of underground water into the shaft and their absorption (infiltration) into tectonically disturbed strata and a geological cross section. The range of redox indicators of mine water is for $\mathrm{pH} 2-8.3$, for $\mathrm{Eh}(+200)-(+500) \mathrm{mV}$ [9]. The results of underground water analysis from observation wells Nos. 49 and 50 (Fig. 1) are shown in the Table. 

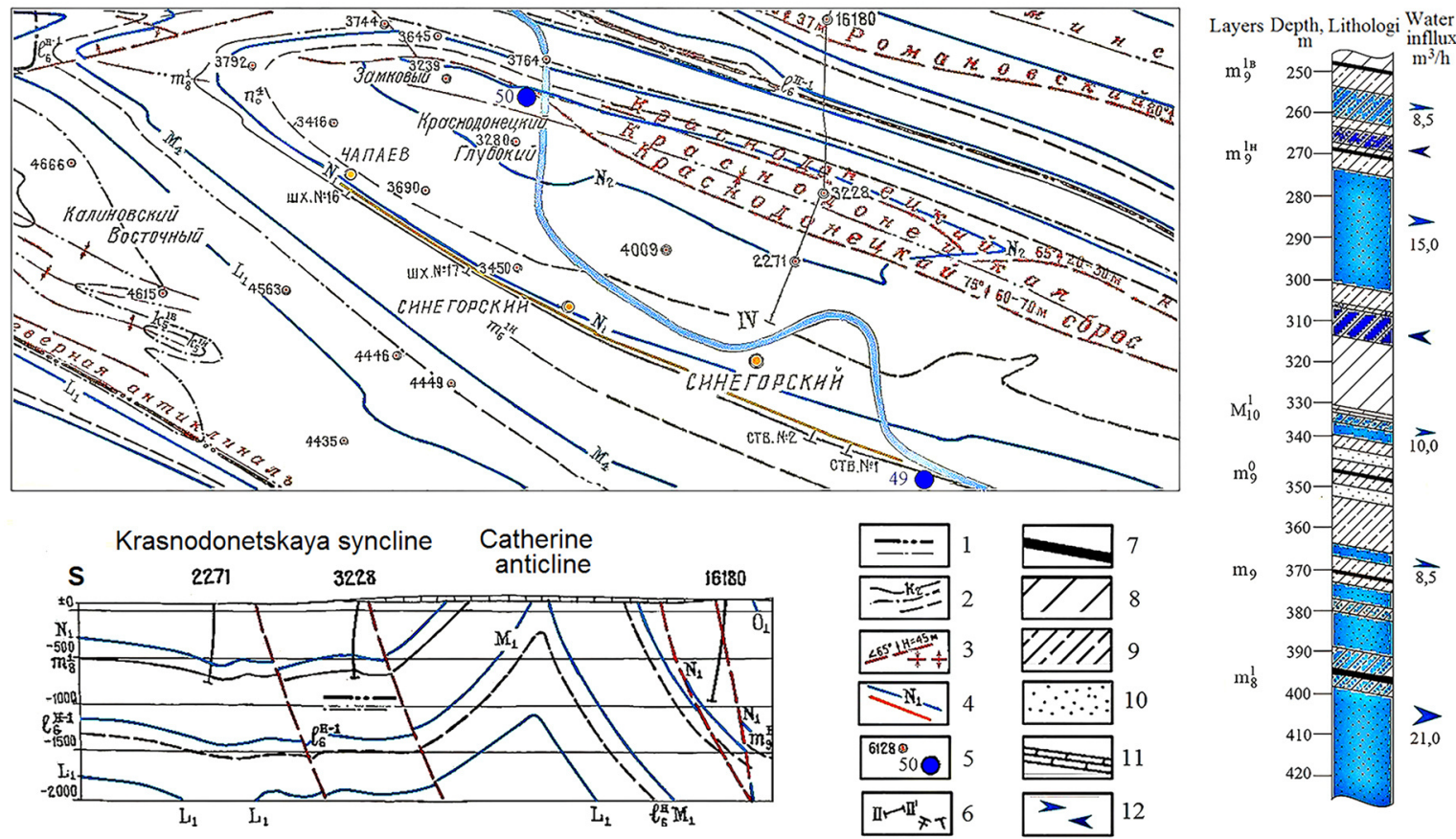

Fig. 1. Geological map and lithological column of the ventilation shaft, "Sinegorskiy" geological section along the line IV:

1 - border of geological-industrial districts and mining fields; 2 - the output of coal seams beneath the cover sediments; 3 - faults and the axis of synclinal and anticlinal; 4 - outlet of limestone and location of geophysical profile; 5 - exploration and observation wells; 6 - lines of geological sections and the location of the inclined shafts; 7-12-layers of coals, shales, siltstones, sandstones, limestones and region of the spout and the absorption of groundwater

Table

Results of the groundwater analysis in the monitoring wells no. 49 and 50

\begin{tabular}{|c|c|c|c|c|c|c|c|c|c|}
\hline \multirow[b]{2}{*}{ No. of wells } & \multicolumn{9}{|c|}{ Water quality indicators } \\
\hline & $\begin{array}{l}\mathrm{pH}, \\
\text { units }\end{array}$ & $\begin{array}{c}(\mathrm{Na}+\mathrm{K}), \\
\mathrm{mg} / \mathrm{dm}^{3}\end{array}$ & $\begin{array}{c}\mathrm{Ca}, \\
\mathrm{mg} / \mathrm{dm}^{3}\end{array}$ & $\begin{array}{c}\mathrm{Mg} \\
\mathrm{mg} / \mathrm{dm}^{3}\end{array}$ & $\begin{array}{l}\mathrm{HCO}_{3}^{-}, \\
\mathrm{mg} / \mathrm{dm}^{3}\end{array}$ & $\begin{array}{c}\mathrm{Cl}^{-}, \\
\mathrm{mg} / \mathrm{dm}^{3}\end{array}$ & $\begin{array}{c}\mathrm{SO}_{4}^{2+} \\
\mathrm{mg} / \mathrm{dm}^{3}\end{array}$ & $\begin{array}{l}\mathrm{Fe}_{\text {total }} \text {, } \\
\mathrm{mg} / \mathrm{dm}^{3}\end{array}$ & Mineralization \\
\hline 49 & 6.89 & 471.7 & 272.5 & 165.4 & 366.1 & 605.1 & 1104 & 3.32 & 3024 \\
\hline 50 & 7.44 & 535.3 & 248.5 & 155.6 & 500.4 & 227.3 & 1536 & 0.39 & 3272 \\
\hline
\end{tabular}

The main method for solving the problem of identifying areas of possible infiltration and discharge of underground water on the territory of a closed mine was the NP, which was carried out according to the potential scheme. Measurements were made with a digital multimeter, the input resistance of which according to the test results was equal to $9.8 \mathrm{MOhm}$. Metrological control of the device included checking the polarity. During field observations, a mobile electrode $M$ was connected to the terminal $(+)$, and a stationary electrode $n$ was connected to the terminal $(-)$. The transfer interval of the $n$ electrode was from 100 to $500 \mathrm{~m}$, depending on the terrain conditions. For each transfer cycle, the EMF value was measured, which was entered by a correction with the corresponding sign in the recorded parameters. The shooting was done in $10 \mathrm{~m}$ increments. The method was used, which consisted in the content of non-polarizing electrodes during measurements in cloth covers richly moistened with water. Before measurements, holes in the ground were filled with water from a plastic bottle. This achieved the stability of the measured Unp values. The margin of error was no more than $1.7 \%$. Zero of the NP survey, to which all results are given, was located at the starting point of the profile. The Unp values for the first $200 \mathrm{~m}$ of the profile were in the range of $(-3)-(+16) \mathrm{mV}$.

To study the structure of the section, the EPTS technology was used [10]. The research was performed using a one-way dipole axial installation, in which the feeding dipole was $A B=$ $=100 \mathrm{~m}$, and the measuring dipole was $M N=10 \mathrm{~m}$. The step of moving the $M N$ line was also equal to $10 \mathrm{~m}$. The maximum distance of the dipoles was $600 \mathrm{~m}$. The pickets of the sounding points were marked after $500 \mathrm{~m}$, respectively; the overlap interval for the same-named points for neighboring sounding points was $100 \mathrm{~m}$. The azimuth of the spacings coincided with the direction of the profile. The accuracy of measurements was estimated by an average relative error, which did not exceed $5 \%$. A set of LFE-3 equipment was used during the work. Fig. 2 shows the results of the NP, EPTS, S the plan of mining operations in the area of the exit of the $m_{8}^{1}$ anthracite formation, and a schematic geological and geomorphological section.

Geoelectric features of the section on the segment of the anomalous field of the NP can be estimated by the results of electrical exploration using the EPTS technology.

The section along the stretch of the rocks is relatively sustained, all the curves of the electric sounding are identical in shape and belong to type A. The minimum depth of the dipoles at a distance of $500 \mathrm{~m}$ is estimated at about $100-150 \mathrm{~m}$. The EPTS-3 and EPTS-5 curves show areas of reduced resistances with minimum values of 11 and $7 \mathrm{Ohms} \cdot \mathrm{m}$. In the upper part of the coal-bearing thickness, the $\rho_{a}$ varies in the range of $12-35 \mathrm{Ohms} \cdot \mathrm{m}$. There are no significant anomalies of the repeated form on the overlapping segments of the EPTS graphs presented in the form of electroprofiling, which indicates that the composition of near-surface deposits is quasiuniform. 


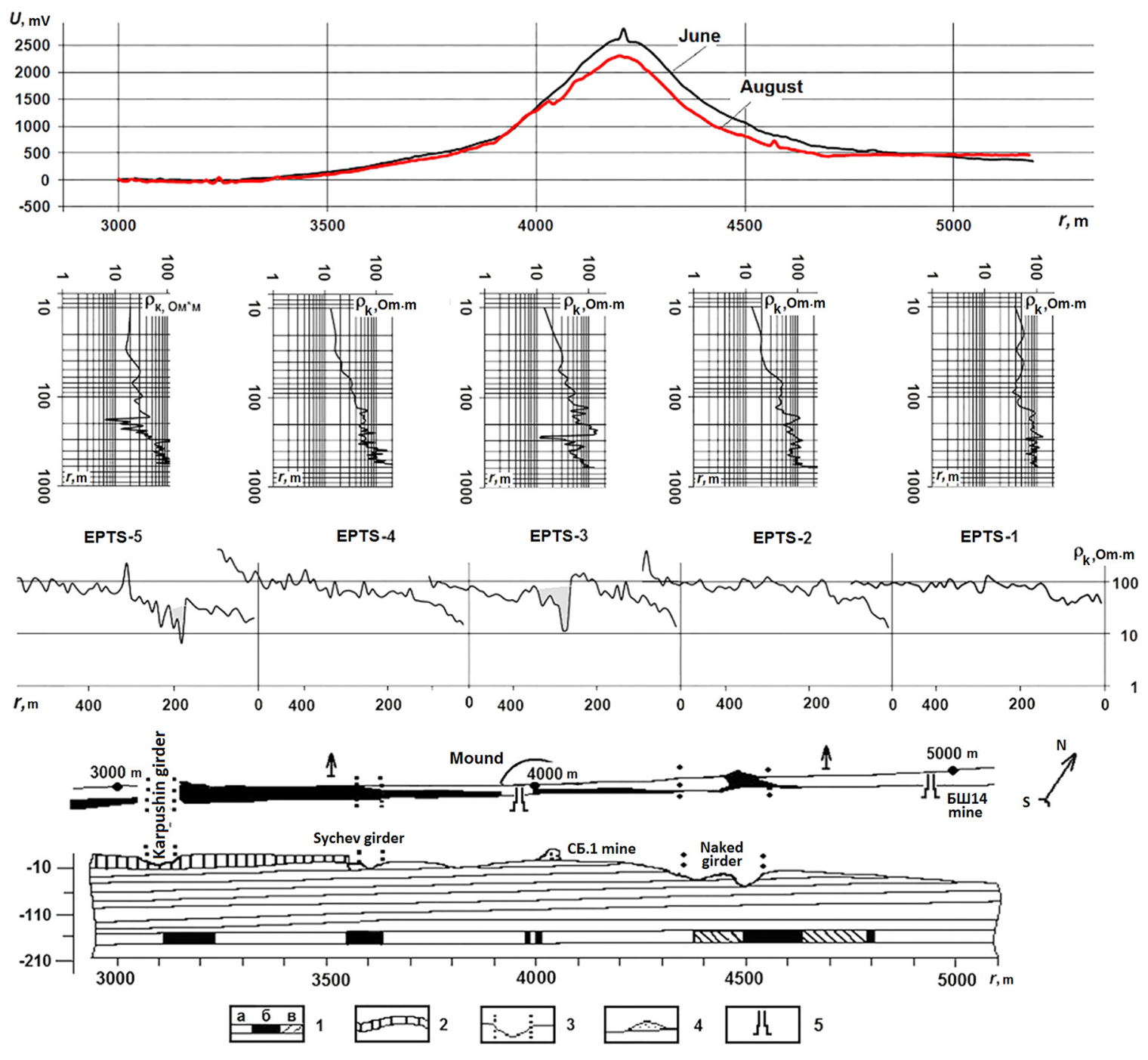

Fig. 2. Graph of NP EPTS curves in the form of electrical sounding and electrical profiling of a fragment of the mining plan in the zone of anthracite formation exit $m_{8}^{1}$ and a schematic geological and geomorphological section along the line of the geophysical profile in the picket range of $3000-5300 \mathrm{~m}$ :

1 - coal seam: $a$ - worked out; $b$ - solid block; $c$ - tectonically disturbed; 2 - outbuildings; 3 - beams; 4 - terricons; 5 - mine shafts and slopes

The Unp graph with abnormally high values of more than $2500 \mathrm{mV}$ draws special attention. The question arises: what can be caused by such an irregular result from the standpoint of modern concepts? We are looking for the answer by considering possible physical, geological and electrochemical processes and phenomena in the conditions of technogenically disturbed coal-bearing strata with electrically conducting coal seams of A1 grade.

Note initially that, according to existing concepts, positive anomalies of the NP field usually occur due to the transfer of charges by the movement of surface and underground waters, i.e. by unloading them (in places where springs appear), as well as on the slopes of hills and mountains The amplitudes of anomalies are the first tens of millivolts and sometimes reach $10-150 \mathrm{mV}$.

Their amplitude depends on the power of the overlapping strata. It is believed that the layers of anthracite are physically and chemically inert. Positive Ups anomalies with an amplitude of up to $250-300 \mathrm{mV}$ are recorded in sections of coal exploration wells above these layers. Confirmation of the inertia of anthracites is that clay crusts appear on these layers in wells (clay particles are attracted from the drilling mud).

The article [1] analyzes the behavior of the PS field in exploration areas with low and intense tectonic disturbance of anthracite strata in the Eastern Donbass.
It is established that natural (tectonic disturbances) and man-made (mining) objects break the electrical chain connecting the oxidation zone with the rest of the formation. In some cases, the current lines are thickened, and there are increased values of potentials; in others, on the contrary, the current lines are rarefied and the potentials are reduced accordingly. Thus, conditions for the formation of inversiontype galvanic elements are created in the coal-bearing thickness. In this context, it is advisable to systematize the data of field observations in order to compile and substantiate a model for the formation of the NP field in a coal-bearing thickness with an anthracite layer developed (absent) in the upper part of this thickness.

Results. The nature of the unique length and intensity of the positive NP anomaly, which is registered in the site technogenically disturbed due to the excavation of a flat, sloping layer of anthracite to a depth of 500-600 $\mathrm{m}$ in the coal-bearing thickness, is considered against the background of the schematic geological section shown in Fig. 2. The section fragmentally displays the structure of the coal-bearing strata along the line of rock strike, i. e. along the geophysical profile, and represents a horizontally layered thickness of terrigenous rocks in the vertical section. Technogenic disturbance of this thickness is associated with the phenomena of arched collapse of the roof of the spent layer, and with a sufficiently large capacity 
and strength of the roof rocks, their smooth descent to the ground. Consequently, the volume of waste space is ultimately an extended, power-varying flat layer of multi-block fractured rocks with a varying stretch of void-pore space. Since the elimination of the mine was carried out by "wet method", the space of the spent reservoir when it is filled with underground water is a kind of drainage channel. At the same time, we pay attention to the important details for further conclusions, reflected on the section and fragment of the mining plan in the intervals between pickets 3000 and $4000 \mathrm{~m}$ and 4350 and $4800 \mathrm{~m}$ (Fig. 2). In the first segment, the anthracite layer was opened by falling not from its boundary with the roof rocks, but from a certain vertical design mark, i. e., from the roof surface. The upper part of the layer that goes down in the fall is left as a whole to strengthen the roof. This is usually provided by projects in areas of gullies, gullies, and if there are industrial and social ground structures on the daytime surface. In the second segment, the coal seam of the $m_{8}^{1}$ formation is tectonically disturbed, which is recorded in the geological documentation of mining operations. This is a system of step-bystep and sub-concordant discharges. Therefore, the following arguments about the effect of the two types of phenomena known during the creation of the NP, electrochemical and electrokinetic, will be made taking into account the designated geological features. Accordingly, electrochemical phenomena are true for solid coal, while electrokinetic ones occur due to filtration processes (the slope of the terrain is observed from the picket 3000 (the area of the Karpushkin beam) to the picket 5000 (the place of the mine shaft Bsh1)) and, to a small extent, diffusion-adsorption processes in the near-surface layer.

A qualitative analysis of the formation of the NP field, for our specific case, is performed by creating a simplified model of a technogenically disturbed anthracite formation in the form of an asymmetric synclinal fold (Fig. 3).

Double electrical layers are shown at the interface, as well as the transfer of positive charges by the flow of underground water. Next, as the first step, we analyze the NP graph on the segment from the $3000 \mathrm{~m}$ picket to the $4000 \mathrm{~m}$ picket (Fig. 2). Here, the profile passes through the previously mentioned high-conductivity roof solid block, which is clearly displayed on the geoelectric section by low electrical resistivity and negative values of small NP values (the first ten units of millivolts). In an undisturbed environment, we would expect an anomaly of negative values up to the first hundred millivolts, but this does not happen. The second step of the analysis is actually to consider the positive, high-amplitude (up to $2500 \mathrm{mV}$ ) an EP anomaly with a span of more than $1 \mathrm{~km}$. An anomaly was recorded between the pickets of $3500-4700 \mathrm{~m}$ with a pronounced gradient effect in the range of $4000-4500 \mathrm{~m}$ pickets. This interval is located between the beams of Sychev and Go-

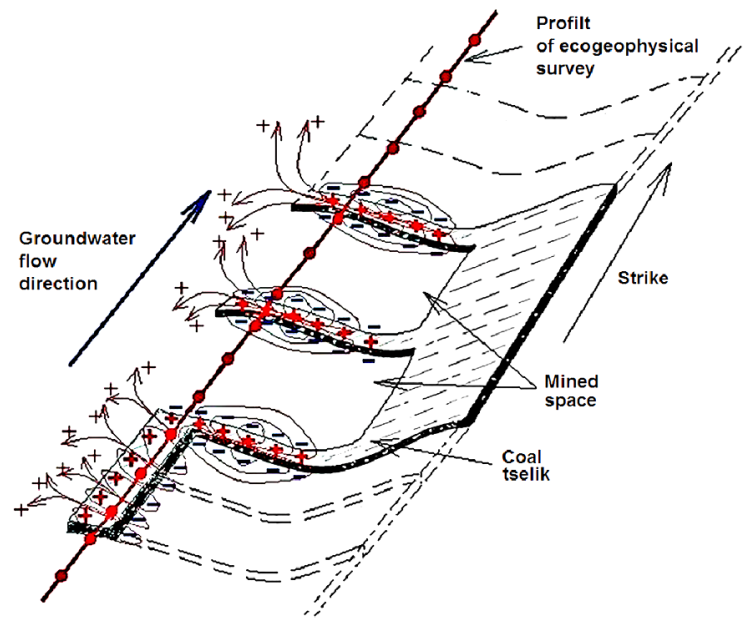

Fig. 3. Model of technogenically disturbed anthracite formation laya, where coal pillars are left. The coal seam between them is completely worked out. We assume: a) in the intervals of the developed reservoir filled with water, there is predominance of filtration processes and, possibly, a slight effect of adsorptiondiffusion; b) over the solid blocks, including the places of strengthening of the roof, the action of redox processes occurs; c) in the presence of a soil layer, there is also a slight influence of adsorption and diffusion processes.

There is a judgment about the presence of a positive anomaly of a large magnitude by the action of very intensive filtration of underground mine water, provided that there must be a structure of a local canyon of sufficient size for "rapid absorption" of these waters. Could it be? The answer is more positive than negative. The situation is similar to hydrogeological pumping [7]. However, when pumping out, the intensity of the anomaly on the mountain branch is several times greater (Fig. 4).

It is logical to assume that the horizontal flow of groundwater into the mined-out seam in the chainage interval 4000 $4500 \mathrm{~m}$ abruptly changes the direction in the vertical due to the presence of "near-vertical funnel" formed in a zone of tectonic dislocation. The continuation of the movement of the horizontal stream is limited entirely by the protective pillar. The flow sign remains positive. The depth of the most intensive discharge is predicted in the area of 120-140 m, which follows from the graphical (tangent) interpretation of the Unp anomaly. It should be assumed that a water-absorbing funnel was formed in the coal-bearing thickness. They can be formed on the mountain branches of existing and, to a greater extent, closed mines. As a rule, the formation of such local zones is associated with tectonic disturbances. In this example, indirect evidence can be the presence of a tectonic disturbance recorded during mining operations in the picket range of $4250-4800 \mathrm{~m}$. In addition, it was in this zone that intense methane release was recorded by mine geologists during operational work. Examples of gas occurrences are also known at other mines in the Donetsk basin [11, 12]. The filtration process is explained in [13]. A diagnostic feature is the discrepancy between the shape of the Unp and the shape of the apparent resistance graphs. The effect of filtration processes in the formation of NP anomalies can be considered on the example of a separate capillary. The theory is borrowed by geophysicists from colloid chemistry and is used in the interpretation of NP anomalies on various geological objects [7].

The potential flow is calculated by the formula of Helmholtz-Smoluchowski equation

$$
E_{\tau}=\frac{P^{\prime} \varepsilon \varepsilon_{0} \cdot \zeta}{\eta^{\prime} \sigma} .
$$

Using the (1), knowing the flow potential in the value of $2.35 \mathrm{~V}$ for the case considered in this article, it is possible to estimate the value of the pressure $P$ that drives the liquid in motion in the first approximation. When calculating, we take the average values for underground waters of the Eastern Donbass: 1) Zeta potential at $\mathrm{pH}=3.5$ equal to $2.9 \cdot 10^{-3} \mathrm{~V}$; 2) medium viscosity $\left.\eta \sim 1.3 \cdot 10^{-3} \mathrm{PA} \cdot \mathrm{s} ; 3\right)$ specific electrical conductivity $\sigma \sim 0.17 \mathrm{Ohms}^{-1} \cdot \mathrm{m}^{-1}$. As a result of calculations, we get at $P \sim 0.25 \mathrm{MPa}$. A priori, equation (1) for a single capillary is applicable to any porous partition in the same form and, in this case, it describes the potential difference on different sides of this partition. The zone of development (displacement crack) of a tectonic discontinuity, which is a porous layer, can also be considered as the above-mentioned partition. The nature of the effect is such that a double electric layer appears on the surface of rocks in contact with the crack (either due to the adsorption of ions from the groundwater solution that fills the crack, or due to surface dissociation). As a result, the stationary surface is negatively charged, and the solution is positively charged (consisting of mobile cations). The movement of the solution (due to pressure difference) shifts the centers of negative and positive charges, there is a potential difference in the 

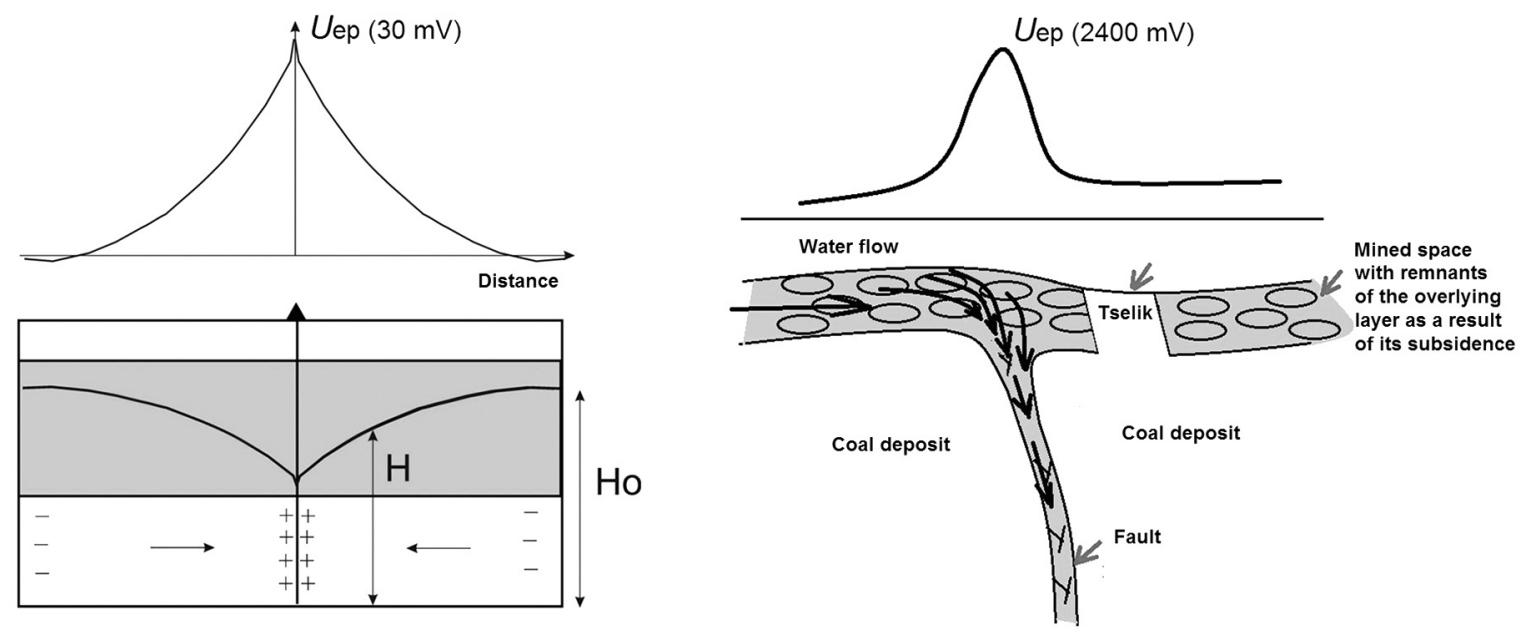

Fig. 4. Models of the formation of a natural electric field when pumping from well (according to Titov, Konosavsky) and in zone of the articulation developed and filled with underground water space with tectonic discontinuity

direction of movement of the fluid and the magnitude of the potential difference does not matter whether fluid flows through one capillar or capillary network. The main criterion is the charge separation coefficient between the solid surface and the solution. The latter is determined by the electrokinetic potential, and the flow rate is determined by the pressure difference.

The width of the underground water filtration zone in the coal bearing column can be estimated using the formula for calculating lateral geostatic pressure

$$
z=\frac{P}{\rho_{m} \cdot g},
$$

where $\rho$ is the density of rocks; $g$ is the acceleration of gravity; $z$ is the width of the partition. Assuming the average density of the coal-bearing massif at the conversion stage with A1 coals equal to $\rho=2.6 \cdot 10^{-3} \mathrm{~kg} / \mathrm{m}^{3}$, the $z$ value will be $10 \mathrm{~m}$, which does not contradict the data of drilling and logging of coal wells that have crossed discontinuous tectonic disturbances.

The third step is to analyze the NP field on the section of the profile between pickets 4700 and $5500 \mathrm{~m}$. Here, the Unp graph is characterized by positive values of $500 \mathrm{mV}$, which remain almost unchanged throughout this section. At the same time, in the intermediate measurement cycle in the picket range of 4310-4820 $\mathrm{m}$ (the section of the profile between the stationary electrode sites $N$ ) the presence of a negative anomaly with an amplitude up to $-1700 \mathrm{mV}$ was recorded (Fig. 5). Therefore, in view of the total positive anomaly, we must assume the combined effect of electrochemical and electrokinetic processes in the formation of the NP field. The first ones take place above, and the second ones - below the coal seam, where the worked-out space is filled with water (Fig. 5).

Conclusion. The result of the research was the discovery of a unique intensity and width of a positive anomaly of the natural constant electric field in the territory of the mining branch of the coal mine liquidated by wet conservation method in the Eastern Donbass. Hypothetically, the nature of the phenomenon is due
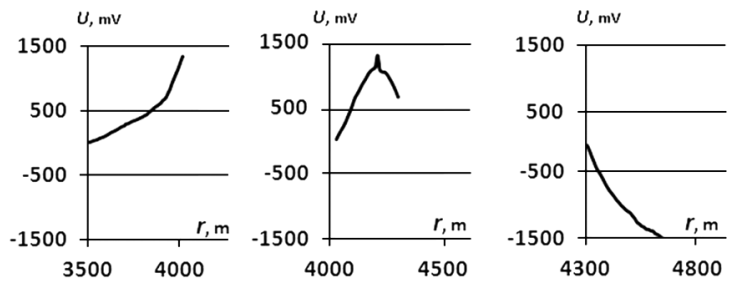

Fig. 5. NP graphs on conjugate sections of the profile bounded by the stationary electrode points to large-scale filtration process in the conditions of sharp changes of ground water flow in hollow space of the developed layer of anthracite to sub-vertical funnel formed at the junction of mining and tectonic faulting. The effect of redox processes on the formation of the NP field in places left as protective pillars of coal seams and, to a small extent, diffusion-adsorption processes in the soil layer of cover deposits is not excluded. The author hopes for a discussion on this issue with the involvement of specialists in the field of electrical exploration.

The author is grateful to associate Professor E. G. Porfilkin for joint work in field observations and doctor of chemical Sciences I. N. Shcherbakov for advice on electrokinetic and electrochemical processes in natural environments.

\section{References.}

1. Fomenko, N.E., Popov, V.V., Porfilkin, E.G., \& Tretyak, A. Ya. (2017). Spontaneous polarization in tectonically disturbed anthracite strata of mountain territories (on the example of Eastern Donbass). Sustainable development of mountain territories, (3), 295-306.

2. Erofeev, L. Ya., Orekhov, A. N., \& Erofeeva, G. V. (2017). Natural electric fields in the gold deposits of Siberia: structure, nature and connection with gold bodies. Geology and Geophysics, (58), 1234-1241. https://doi.org/10.29202/nvngu/2018-2/2. 3. Orekhov, A.N. (2015). Informativeness of geophysical methods in the search for gold mineralization in black-shale strata. Notes of the mining Institute, (212), 117-121.

4. Jackson, M. D. (2015). Self-Potential Methods Author links open overlay panel. Reference odule in Earth Systems and Environmental Sciences. Treatise on Geophysics (Second Edition), (11), 261293.

5. Sungkono, D., \&Warnana, D. (2018). Black hole algorithm for determining model parameter in self-potential data. Journal of Applied Geophysics, 148(1), 189-200. https://doi. org/10.1016/j.jappgeo.2017.11.015.

6. Collins, J., Gourdin, G., Foster, M., \& Qu, D. (2015). Carbon surface functionalities and SEI formation during Li intercalation. Review Article, Carbon, 92(10), 193244.

7. Titov, K., Konosavsky, P., \& Narbut, M. (2015). Pumping test in a layered aquifer: Numerical analysis of self-potential signals. Journal of Applied Geophysics, (123), 188-193. https:// doi.org/10.1016/i.jappgeo.2015.10.006.

8. Shevnin, V.A., Ryzhov, A. A., \& Kvon, D. A. (2015). Interesting scientific fact-strong anomalies of the ore-free nature EP. Geophysics, (2), 2-8.

9. Fedorov, Yu. A., Dotsenko, I. A., \& Dmitrik, L. Yu. (2016). Iron in surface and underground waters of the Azov sea basin. Proceedings of higher educational institutions, North Caucasus region, Natural Sciences, (3), 91-99. 
10. Fomenko, N.E., Porfilkin, E.G., \& Gaponov, D.A. (2017). Investigation of the geological environment by the method of electropotential tomographic sounding for the purpose of selecting places for safe placement of industrial and household waste. Geophysics, (1), 63-71.

11. Gasaliyev, M.A., Portnov, V.S., Komarov, R. K., Mausymbayeva, A. D., \& Yurov, V. M. (2015). Geophysical studies of zones of high gas content coal seams. Naukovyi Visnyk Natsionalnoho Hirnychoho Universytetu, (6), 24-30.

12. Kamarov, G. K., Zamaliev, N. M., Akhmatnurov, D. G., \& Musin, R.A. (2018). Establishing the volume and location of gas collectors of liquidated coal mines. Naukovyi Visnyk Natsionalnoho Hirnychoho Universytetu, (2), 5-11. https://doi. org/10.29202/nvngu/2018-2/2.

13. Shevnin, V.A. (2019). Recognition of the nature of EP anomalies - an important step in qualitative interpretation. Geophysics, (1), 21-24.

\section{Аномалія природного постійного електричного поля великої величини в техногенно-порушених пластах антрациту}

\section{М. С. Фоменко}

Інститут наук про Землю Південного федерального університету, м Ростов-на-Дону, Російська Федерація, e-mail: fnegeophyskohle@yandex.ru

У Східному Донбасі на гірничому відведенні ліквідованої способом мокрої консервації шахти, шо розробляє вугільні пласти антрациту марки A1, отримана великої величини (інтенсивністю до 2500 мВ і шириною більше 1 км) позитивна аномалія постійного природного електричного поля (ПП). Повторні (контрольні) вимірювання, проведені через два місяці, підтвердили наявність цієї аномалії. Авторське трактування природного феномена зводиться до багаторівневого, покрокового аналізу умов формування поля природних потенціалів у техногенной тектонічно-порушеному гірничими роботами масиві вугленосних порід.

Мета. Встановлення закономірностей формування позитивної аномалії постійного природного електричного поля великої величини на гірничому відведенні ліквідованої шахти.

Методика. Польові геофізичні роботи методами ПП і електропотенціального томографічного зондування (ЕПТЗ). Багаторівневий, покроковий аналіз умов формування поля природних потенціалів у техногенно- й тектонічно-порушеному гірськими роботами масиві вугленосних порід.

Результат. Розроблена модель гідроелектрокінетичного розрізу, в якому вироблений простір представлено обводненим протяжним і мінливим за потужністю пласким пластом різноуламкових тріщинуватих порід з утворенням у місці прояву тектонічної порушеності водопоглинаючої воронки, як структури швидкісного поглинання шахтних вод, що приводить, унаслідок інтенсивної інфільтрації, до формування позитивної аномалії ПП величиною більше 2, 3 В.

Наукова новизна. Виявлення та обгрунтування закономірностей утворення унікальної за інтенсивністю й шириною позитивної аномалії природного постійного електричного поля на території гірничого відводу ліквідованої вугільної шахти у Східному Донбасі.

Практична значимість. Унікальність виявленої позитивної аномалії ПП ініціює дискусію про характер іiі утворення та доводить доцільність застосування методу ПП при вирішенні завдань гідроекологічного, газового та інших видів моніторингу у вугільних регіонах.
Ключові слова: природнє постійне електричне поле, Східний Донбас, антрацит, техногенно-порушені пласти, електророзвідувальні дослідження, гірничі відводи закриmux maxm

\section{Аномалия естественного постоянного электрического поля большой величины в техногенно-нарушенных пластах антрацита}

\section{Н. Е. Фоменко}

Институт наук о Земле Южного федерального университета, г. Ростов-на-Дону, Российская Федерация, e-mail: fnegeophyskohle@yandex.ru

В Восточном Донбассе на горном отводе ликвидированной способом мокрой консервации шахты, разрабатывающей угольные пласты антрацита марки A1, получена большой величины (интенсивностью до 2500 мВ и шириной более 1 км) положительная аномалия постоянного естественного электрического поля (ЕП). Повторные (контрольные) измерения, проведенные через два месяца, подтвердили наличие этой аномалии. Авторская трактовка имеющего место природного феномена сводится к многоуровневому, пошаговому анализу условий формирования поля естественных потенциалов в техногенно- и тектонически-нарушенном горными работами массиве угленосных пород.

Цель. Установление закономерностей формирования положительной аномалии постоянного естественного электрического поля большой величины на горном отводе ликвидированной шахты.

Методика. Полевые геофизические работы методами ЕП и электропотенциального томографического зондирования (ЭПТЗ). Многоуровневый, пошаговый анализ условий формирования поля естественных потенциалов в техногенно- и тектонически-нарушенном горными работами массиве угленосных пород.

Результаты. Разработана модель гидроэлектрокинетического разреза, в котором выработанное пространство представлено обводнённым протяжённым и изменяющимся по мощности плоским пластом разнообломочных трещиноватых пород с образованием в месте проявления тектонической нарушенности водопоглощающей воронки, как структуры скоростного поглощения шахтных вод, приводящей, в силу интенсивной инфильтрации, к формированию положительной аномалии ЕП величиной более 2,3 В.

Научная новизна. Обнаружение и обоснование закономерностей образования уникальной по интенсивности и ширине положительной аномалии естественного постоянного электрического поля на территории горного отвода ликвидированной угольной шахты в Восточном Донбассе.

Практическая значимость. Уникальность выявленной положительной аномалии ЕП инициирует дискуссию о характере ее образования и доказывает целесообразность применения метода ЕП при решении задач гидроэкологического, газового и других видов мониторинга в угольных регионах.

Ключевые слова: естественное постоянное электрическое поле, Восточный Донбасс, антрацит, техногенно-нарушенные пласты, электроразведочные исследования, горные отводы закрытых шахт

Recommended for publication by B. I. Zhurbytskyi, Doctor of Geological and Mineralogical Sciences. The manuscript was submitted 27.03.20. 